\title{
Paradoksaalsed igapäevakujut(l)used? Narratiivsed persoonid, pärisustamine ja "Halvale teele"1
}

\author{
Siim Sorokin \\ Tartu Ülikooli kultuuriuuringute teadur \\ siim.sorokin@ut.ee
}

Teesid: Artikkel tutvustab ja arendab edasi minu doktoriväitekirja teoreetilisi ja analüütilisi võtmepositsioone. Väitekirjas keskendusin narratiivse tegelaskujuga suhestumise uurimisele teleseriaali "Halvale teele" netiretseptsioonis väljenduva digitaalse jutuvestmise mikroanalüüsi põhjal. Artikkel on jagatud kolme omavahel üsna tihedalt seotud ossa. Esimeses räägin mõne sõnaga üleüldiselt ameerika teleseriaalist "Halvale teele" (Breaking Bad). Teises toon välja pakutava teoreetilise raamistu võtmemõisted ja pakun lühidat neist tõukuvat empiirilise allikmaterjali analüüsi, mis on ühtlasi mõeldud analüütiliselt illustreerima kolmanda alaosa teoreetilise kontseptualiseerimise vettpidavust. Seega on artikli kolmas alaosa eelnevaga otseselt seotud, kuna skitseerin analüüsist juhinduvalt teoreetilised järelmid, pearõhuga eelnevalt välja töötatud mõistestikul. Eeskätt keskendun neist kolmele: narratiivne persoon, pärisustamine (realitization), ja kaastoimeliselt arenduv loominguline rahvakeel (co-elaborative creative vernacular). Narratiivse persooni kontseptsioon on mõeldud vastukaaluks mehhanistlikule, seespidisele teadvussõltvuslikule (internalist, mind-dependant) nägemusele fiktsionaalse karakteri kogemisest. Minu käsitluses on narratiivne persoon suveräänne - oma eluilma asustav - toimija (agency), kellest - otsekui teisest pärisinimesest - vaatajad järk-järgult üha enam kütkestatud on (absorbed by), selmet nad temasse "neelduks" (absorbed "in") või end temaga samastaks (identify with). Eelnimetatud baaseelduste valguses muutub aga küsitavaks seespidiste kogemuslikkusmudelite - kas siis laiemalt narratiivi või kitsamalt karakteritega suhestumise - universaalne teaduslik rakendatavus. Siinkohal tulebki täpsustava mõistetasandina mängu pärisustamise kontseptsioon. Sellega tõstan esile pärisusloome (realmaking) diskursiivset praktikat, mis ilmneb karakteritega suhestumise väljendusvormelite pinnalt eeskätt just (digi)kogukondliku - ühistoimeliselt kaasarendatava (co-elaborative) ja selliselt kaasarenduva - arutelu tingimustes. Antud arutelu väljendub (digi)materiaalsete kommentaaritekstide ja foorumipostituste kui narrtseptide (narrcept; narratiiv+pertsept; ingl narr[ative] + [per]cept[ion]), s.o narratiivselt seadistatud tajuväljundite näol. Eelöeldust tulenevalt kasvabki pärisusloome mõiste välja kolmandast instrumentaalsest kontseptsioonist - nimelt ühistoimeliselt kaasarenduvast loomingulisest rahvakeelest. Antud käsitusega piiritlen kogukondlikult edastatavat ja edendatavat teise-suunalist (other-directed) jagatud tähendusloomet, mis kaasarendub 
narratiivselt, tuginedes sotsiaal-materialistliku iseloomuga ja argitarkusliku põhistusega igapäevakeelekasutusel ja vastavalaadsetel mõtlemisprotsessidel.

Märksõnad: "Halvale teele", igapäevakeel ja -kujut(l)used, narratiivi sotsiaalmaterialism, narratiivne persoon, narratiivse kogemuslikkuse pragmaatika, narratiivselt "seadistatud" keelekasutus, pärisustamine, pärisusloome

Käesoleva artikli eesmärk on pakkuda ülevaadet mu doktoriväitekirjas välja töötatud teoreetilistest ja analüütilistest võtmepositsioonidest (vt Sorokin 2018a). Dissertatsiooni empiiriline materjal pärines ameerika teleseriaali "Halvale teele" (Breaking Bad; televõrk AMC, 2008-2013) netidiskursusest (televisioonikriitikablogide kommentaariumid ja foorumikeskkondade arutelulõimed). ${ }^{2}$ Artikli ülesehitus on järgmine. Esiteks annan lühikese sisuülevaate seriaalist "Halvale teele" (alaosa 1). Järgneb illustratiivne empiiriline analüüs (alaosa 2). Analüüs niihästi kohandab kui ka taasloob mu varasemat uuringut (Sorokin 2018a, ptk 3). Rakendatud kvalitatiivses lähianalüüsis olin inspireeritud hiljutisest "mikroanalüütilisest" lähenemisest netidiskursuste andmestikule, kuid leidsin praktilist hõlbustavat kasu ka arvutuslikest andmekaeve ja nn loomuliku keele töötlemise meetoditest (vt nt Giles jt 2015, 2017). Vormilt määratlesin oma analüüsi metatasandilise vaatleva "jutustusena jutustamisest" (vt Sorokin 2018a: 145-153, eriti lk 147). Ühelt poolt on seega teise alaosa eesmärgiks illustreerida mujal pakutud terviklikku analüüsi (Sorokin 2018a: 150-177). Teisalt on käesolev analüüsivorm kasutusel metafoorse "sissepääsuna", kuna nii saab võimalikuks viidata mitmesuguste teoreetiliste implikatsioonide ilmnemisele. Need järelmid omakorda kannustavad süvenenumat teoreetilist arutelu alaosades 3 ja 4 . Nimetatud alaosades keskendun narratiivselt arenduva, teisele suunatud ja kolmanda isiku perspektiivilt sõnadesse pandud kogemuslikkuse (alaosa 3) ja positiivse karakteriontoloogia (affirmative character ontology, alaosa 4) teoreetilisele väljaarendamisele. Kirjeldatud artiklistruktuuril on selgepiiriline retooriline taotlus. See osundab, et analüüsita poleks teooriat ja vastupidi. Siinkohal on kohane täheldada sedagi, et alljärgneva artikli huviorbiidis on eranditult televisioonivaatajate ja -kommenteerijate netidiskursuse omapärad - iseäranis selles osas, mis puutub suhestumisse narratiivsete tegelaskujudega. Tuumväide: kogukondliku arutelu tasandil käsitatakse viimaseid narratiivsete persoonidena (siit ka "paradoksaalsed igapäevakujut(1)used"). Seega tasub märkida, et televisuaalse narratiivi kui sellise analüüs jääb ilmselgelt väljapoole käesoleva artikli huvikeset. 


\section{Sissejuhatuseks}

Vince Gilligani seriaal "Halvale teele"3 pälvis juba üsna varakult publiku- ja kriitikamenu. Seda hakati iseloomustama kui kvaliteetseriaali, mis pakub vaatajale "narratiivset keerukust" niihästi süžee kui ka "moraalselt tumedate" tegelaskujude tasandil. Nii on omaette sümboliks kujunenud ka Gilligani lause, millest sai esialgse looidee promo televõrgule AMC: "See on lugu mehest, kes muundab end õpsist Arminäoks." Oma hiljutises raamatus (Sepinwall 2012) on ameerika üks esitelekriitikuid Alan Sepinwall tõdenud, et sarnaselt seriaalidega "Sopranod", "Võrgustik" (The Wire), "Deadwood", "Pöörased" (Mad Men) ja "Teadmata kadunud" (Lost) ning uuemast ajast kasvõi "Rectify" on ka "Halvale teele" osaks ulatuslikumast "kuldajastu" paradigmast, mis on aidanud revolutsioneerida mitte ainuüksi televisiooni, vaid ka seda, kuidas vaadatakse. ${ }^{4}$ Seega asus "Halvale teele" jätkama teatavat registrit, mis oli juba mõnda aega vorminud telenarratiividest ja eeskätt tegelaskujudest rääkimise intensiivsust. Mujal ongi Sepinwall tabavalt märkinud, et niisuguste narratiivide tegelaskujudest võiks mainitud seoses rääkida otsekui "elavatest" (või "sisseelatud") inimestest (lived-in human beings). ${ }^{5}$ Siinkohal tasub aga märkida, et iganädalaste kriitiliste arvustuste (ning nendega kaasnevate kommentaariumite) formaati inspireeris kaheldamatult juba aastaid varem televaatajate endi loodud seriaaliepisoodide kokkuvõtteblogi “Television Without Pity" (ee Halastuseta televisioon), millega käis koos ka ulatuslik edasine arutelu, antud juhul spetsiifilises teadetetahvli-foorumi (bullet-board) vormis. ${ }^{6}$

Eelöeldule vaatamata tuleb aga möönda, et mõistagi ei jõudnud Lääne teletööstus äsjakirjeldatud arenguteni üleöö. Nn keeruka kvaliteettelevisiooni eelkäijaks peetakse episoodipõhiseid protseduuridraamasid (mitmesugused krimi-, haigla- ja kohtusarjad 1980. ja varajastest 1990. aastatest). Nii meenutabki "trendiseadja", "Sopranode" looja David Chase: "Tunnise teleprogrammi vaatamine ei üllatanud mind kunagi. Ja ma ei näinud seal iialgi kedagi, kes oleks käitunud nagu päris inimene" (Sepinwall 2012: 34). Chase'i eesmärgiks sai võimalikult ulatuslik orienteeritus detailidele, püüe "suumida" vaataja pilku "väga väikestele asjadele inimeste kohta" (samas: 313). Antud seoses kirjeldabki näiteks kaasaegse kunsti filosoof ja filmiteoreetik Noël Carroll "Sopranode" peategelase, julma maffiapealiku Tony Soprano (James Gandolfini) teraapiaseanssi: "Tony poolt algatatud kavatsusliku hämamise kihistused, alateadlikud enesepettused, meioosid, keerdsõlmed, silmakirjalikkus ja eksitavad kirjeldused mõjuvad kogu aeg haaravalt; sa võrdled alatasa seda, mida ta ütleb ja millest ta teadlik on, tema tegeliku olukorraga (nii nagu sa tead seda olevat)" (Carroll 2004: 89-90; Sorokin 2018b: 106). 
Samalaadset televisualiseeritud antikangelaste jada jätkab ka "Halvale teele", jutustades loo inimlikust uhkusest ning sellest, kuidas kriminaalse võimu saavutamine ei pruugi mitte üksnes inimest korrumpeerida, vaid võib ka mitmes mõttes võimendada temas seni varjulejäänut. Walter White (Bryan Cranston) on seadusekuulekas, allaheitlik ja vagur pereisa, kes töötab gümnaasiumis keemiaõpetajana, teenides sealjuures palgalisa autopesijana. Siis saab ta aga teada, et põeb vähki ning on ehk aasta pärast juba surnud. Selline traagiline elupööre sunnib teda kasutama äärmuslikke meetmeid, et tagada pere rahalist kindlustatust pärast oma surma. Olles hiilgav keemik, hakkab ta valmistama metamfetamiini ning võtab partneriks oma endise õpilase Jesse (Aaron Paul). Lugu algab esialgu ehk isegi süütult. Oli ju Walteril välja arvestatud täpne rahasummagi, millest piisama peaks. Algul paelus teda tootmisprotsessiga kaasnev teaduslik mõõde. Tagajärgedele ta ei mõelnud. Süües kasvas aga isu. Tulemuseks olid vägivaldsed kokkupõrked diilerite ja ka narkoparunitega, sh Walteri ja Jesse'i hilisema ülemuse, kohaliku maffiabossi Gus Fringiga (Giancarlo Esposito). Kõik need seigad viivad mitmesuguste koletuslike sündmusteni. Ühes paljudest ikoonilistest stseenidest, seriaali lõpuosas "Felina", tunnistab Walter, väsinud enesepettusest ja silmakirjalikkusest, oma abikaasale Skylerile (Anna Gunn), et tegelikult oli tema kõige suuremaks vaenlaseks tema ise: "Ma tegin seda kõike endale. Ma oskasin seda teha. Ja ma... ma tundsin, et olen elus."

Minu empiiriline valim koosnes eelnevalt netiruumis juba arhiveeritud ja minu poolt seejärel vastavalt annoteeritud kommentaaritekstidest ja foorumipostitustest, mis pärinesid kõige populaarsematest telekriitika blogidest ja meelelahutussaitide kolumnidest (Alan Sepinwalli "What's Alan Watching?" Uproxx.comis; "The A. V. Club"; Tim Goodmani "Bastard Machine" Hollywood Reporteris) ning kasutajate algatatud ja modereeritud lõimedest Redditi r/breakingbad ala-redditis. ${ }^{8}$

\section{Teel teooriani analüüsi kaudu. Katkeid "Halvale teele" tegelaskujude tähendusloomest ja selle lähianalüüsist}

Antud alaosa eesmärk on pakkuda analüütilist talastikku kolmele kaalukaimale omavahel seotud mõistele minu teoreetilises raamistus (Sorokin 2018a): pärisustamine (realitization), narratiivne persoon (narrative person), ja ühistoimeliselt kaasarenduv loominguline rahvakeel (co-elaborative creative vernacular). Alljärgnevalt pakun analüüsikatkeid, mis keskenduvad diskursiivsetele operatsioonidele netivestluses, mida rakendatakse juhul, kui kõne 
all on sarinarratiivi (s.o "Halvale teele") tegelaskujud. Säärased operatsioonid võimaldavad esile tõsta erilaadseid aspekte online keskusteludes, osundades empiirikast johtuvale vajadusele välja töötada kohane teoreetiline mõistestik. Antud seoses pakubki minu adapteeritud argitarkuse ${ }^{9}$ kontseptsiooni käsitlus võimalust selgepiirilisemalt hoomata kogukondlik-individuaalse loomingulise jutuvestmise väljenduslikke strateegiaid, mille ma olen määratlenud koondnimetusega ühistoimeliselt kaasarenduv loominguline rahvakeel (vt Sorokin 2018a: 23-39).

Mõiste "kaasarenduv" olen siinkohal kohandanud "teadmuse kaasarenduvuse" kontseptsioonist, mis oma algupärasel kujul töötati välja digitaaldisaini alal (vt Détienne jt 2012; vrd Détienne jt 2017; Bacchilega 2015; Banks \& Humphreys 2008). Minu teoreetilises sõnavaras annab antud mõiste eksplitsiitselt märku kommenteerijate ühisest, jagatud teisele-suunatud huvi (st huvist teiste inimeste vastu, olgugi, et nominaalselt on need fiktsionaalset tüüpi) operatiivsest kvaliteedist. Seega, kui ütlen kaasarenduv, osundan ühishuvile (common interest), mida edastatakse (communicate) ja edendatakse (develop) kogukondlikult asünkroonselt mitmes diskursusruumis, ent mis sellegipoolest ka dialoogiline olles arendub nende ruumide üleselt. Äsjakirjeldatu on illustreeritav, kui netivestlustes jälgida mõningaid diskursiivseid fokaalpunkte, mille keskmes on televaatajate-netivestlejate suhestumine "Halvale teele" tegelaskujudega. Nii on mitmedki aruteluteemad inspireeritud pealtnäha lihtsakoelistest šüžeelünkadest, mis aga lähimal vaatlusel annavad kiirelt mõista, et antud (sisulised) ambivalentsid võivad kujuneda hoopis keerukamaks kui pealiskaudsel ülevaatusel ehk näida võis. Näiteks ühel nädalal arutleti teatava narratiivse lünga üle, nt kes tegi seriaalis "Halvale teele" kellele mida, miks üks või teine tegelaskuju just nii toimis (s.t narratiivsete persoonide tajutav agentsus) ning kuivõrd sobitatavad ja ühtlustatavad on arutlejate esmased jutustuslikud ennustused stsenaristide toimimisega, s.o nende lõplike looliste valikutega, iseäranis mis puutub teatavatesse narratiivsetesse persoonidesse. Juba nädal hiljem, pärast teatavaid (narratiivseid) sündmusi võidi needsamad valikud aga vaidlustada; eeskätt selle tõttu, et need tundusid õonestavat narratiivsete persoonide senist elukäiku arutlejate jaoks akumuleerunud narratiivse informatsiooni põhjal. Teisisõnu jõuame lõpuks välja kriitilise küsimuseni: kuidas (kui üldse) on publikueeldused kokkusobitatavad lõplike autorijutustuslike valikutega?

Eelkirjeldatud vaidluskohtade lõikuvuse algtasand väljenduks kogukondlikul pinnal tõepoolest juba üksnes kahe kommentaariteksti dünaamikas ja vaid ühe nädala näitel. Alljärgnevas näites (vt näidet 1) pakutava dialoogilise vestluse tekstid on postitatud veidi rohkem kui ööpäevase vahega teleseriaali "Halvale teele" neljanda hooaja ühe võtmeepisoodi "End Times" järgsel nädalal. ${ }^{10}$ 


\section{Näide 1}

Justin "Kas nii võib olla, et kogu see asi oli viga?” Jep. See lõi mulle esimesena pähe (et tegemist oli juhusliku mürgitamisega), kuni nad sisse viskasid, et tõenäoliselt oli mürgitajaks kas Gus või Walt. Ja see [et tegemist on veaga] tundubki peaaegu, et kõige tõenäolisema stsenaariumina. Mida rohkem ma sellele mõtlen, seda enam ma kahtlen selles, et Gus Brocki mürgitas. Tundub justkui liiga palju oleks pidanud lühikese aja jooksul juhtuma, et see nii olnud oleks. Ka Waltil polnud mingisugust realistlikku võimalust saada kätte nii ritsiin KUI KA Brock. Igatahes see pole täielikult vastuvõetav, et Gus VÕI Walt oleksid suutnud säärase ülepaisutatud plaani ellu viia, ehkki kindlasti oleks võimalik leida stsenaariumeid, mis sobiksid (nt keegi mürgitab Brocki MILLEGAGI ja varastab seejärel [ritsiini] sigareti, et Jesse arvaks, et tegemist oli ritsiiniga, kui [tegelikult] oli see midagi muud, või kes teab). See, et Brock sigaretti suitsetas EI pruugi olla loogiline valik kahel põhjusel; esiteks, Brock peab sigareti üles leidma JA seda suitsetama (võiks loota, et keegi ehk märkaks seda, aga võimatu see pole); ja teiseks, see peaks antud ajavahemikku ära mahtuma (oleksid Brock ja sigarett nende kahe hetke vahel, kus Jesse viimati oma "õnnesigaretti" nägi ja kui ta haigla ees adus, et see kadunud on, olnud ühes ja samas toas?). Need [kaks põhjust] justkui viitaks, et Brock EI teinud Jesset järele ega suitsetanud ühte tema sigarettidest (eeldatavalt siis tagurpidi pööratut [kuhu ritsiiniampull peidetud oli], kuna selle silmatorkavuse tõttu selle ta just krabakski). ${ }^{11}$

(Dave I, Uproxx; http://uproxx.com/sepinwall/breaking-bad-end-timesan-appropriate-reponse/, 3.10.11, 3:07PM)

Kas nii võib olla, et kogu see asi oli viga? Mis siis, kui poisike läks Jesse’i jakitasku kallale ja suitsetas sigareti ära, ja Walt, märgates Jesse irratsionaalset olekut, kasutas seda ära, et teda uuesti enda poolele saada (sarnaselt eelmiste kordadega, kui ta Jesse oma plaanidega kaasa tulema sai). Pean kuulama Jesset rääkimas, kuidas ta ritsiinil silma peal hoidis (see osa näis veidi ebamäärane), aga see [et tegemist oli veaga] oli mu esmane arusaam.

(Justin, samas, 3.10.11, 3:27AM)

Dave I haarab kinni kaasvestleja Justini küsimusest, et vahest polnudki mürgitamine ette kavatsetud. Äkki on kõige keskmes hoopiski "viga"; näiteks see, et pealtnäha eluohtliku ritsiinimürgitusega hospitaliseeritud Brock olevat kuidagi kätte saanud Jesse'i poolt kaasas kantava sigareti, millesse oli peidetud Gusi mürgitamiseks mõeldud ritsiiniampull, ja nõnda end n-ö ise õnnetu 
juhuse läbi mürgitanud. Ehkki Dave I ei jäta Justini teooriat "juhuslikust mürgitamisest" küll kõrvale, läheneb ta sellele läbi stsenaristide toimimise; s.t "juhuslik mürgitamine" võib tõepoolest olla võimalik, lausa "kõige tõenäolisem stsenaarium", kasvõi juba ainuüksi seetõttu, et nii Walti kui Gusi kohta on "nad" (s.o stsenaristid) juba kahtlustusi "sisse visanud" - ehk siis teisisõnu, kummagi narratiivse persooni kasvõi vihjamisi sidumine kõnealuse sündmuse keskmesse võib narratiivi kui terviku tasandil olla stsenaristide kavatsuslik diversioonitaktika.

Analüütilisel tasandil on siinkohal võimalik märkida, et Justini küsimusest tõukuvalt hakkavad Dave I tekstis laiema retseptiivse jutuilma (storyworld; vt Herman 2002) siseselt edenema teatavad "alailmad". ${ }^{12}$ Oma väitekirjas olen sääraseid alailmu näiteks seoses narratiivsete persoonidega - käesolevalt Walt, Gus, Jesse ja Brock - määratlenud nende kui (ontoloogiliselt) suveräänsete toimijate kavatsemisilmadena (intend-worlds). Kuid Dave I ja paljude teiste tekstidest nähtub, et samaväärselt kesksed on ka tekstiloojate-ilmad (text makers'world). Antud seoses pean siis silmas järjepanu edenduvaid väljenduslikvestluslike vormide n-ö virtuaalseid, mõttelisi kogumeid, mille keskmes on ühtaegu narratiivsete persoonide tähendustamisega - vaadeldava narratiivi stsenaristide võimalik toimimine stsenaariumikirjutamisega seotud valikute kontekstis. ${ }^{13}$ Mõistagi on siinkohal ilmne televaatajate-vestlejate kriitiline eritlus suunal "väljamõeldis" ja reaalsus. Konkreetsemalt naasen selle teema juurde alaosas 4 .

Nüüd, kuigi Dave I usaldab Justini tuumargumenti “juhuslikust" enesemürgitamisest - mis põhineb peamiselt päriselulisel arusaamal, et noored lapsed on järelemõtlematult altid proovima n-ö keelatud asju -, jääb ta Walti või ka Gusi osaluse suhtes ülimalt kriitiliseks. Kummagi mehe kaaslus mürgitamises pole Dave I-le "täielikult vastuvõetav", seda enam, et Dave I hinnangul vajaks selline "ülepaisutatud [mürgitamis]plaan" ülimalt läbimõeldud ja osavat viimistlemist. Dave I aga kahtlustab, et see on miski, milleks ei Waltil ega Gusil polnud antud hetkel piisavalt võimalusi. Sellegipoolest tuleb möönda, et Dave I pole täielikult veendunud ka "juhusliku mürgitamise" teooria paikapidavuses. Seega, ehkki Brocki seotus võib küll olla "kõige tõenäolisem" tulem, saaks välja tuua "kaks põhjust", mispärast laps pole "loogiline valik", kellest lähtuvalt kõiki lahtirulluvaid sündmusi keskendada.

Äsjatoodud Dave I ja Justini vaheline jutustuslik 'dialoog' - olgugi, et mitte antud termini ranges tähenduses - osundab kahele omavahel põimunud tendentsile digisuhtluses. Ühelt poolt on kumbki tekst - mida määratlen kui narrtsepti (narratiiv+pertsept inglise keeles percept), s.o üks kommentaaritekst või foorumilõime sissekanne - argitarkusel põhinev loomeline produkt (individuaalne tähendus) (common sense). Teisalt aga, oma mitmetahulistes 
sisulistes kokkupuudetes teistega, "hajustub" ka üksainus säärane tekst osiseks üldisemast, jagatud (distributed) teabest, mistõttu võib kasvõi ühe konkreetse ajaintervalli lõikes täheldada ühise, "kommunaliseeritud" tähenduse väljaarenduvust, rahvapärase kaemuse produktsiooni (common sense). Keskseks loominguliseks "tööriistaks" kujuneb siin narratiiv kui "sotsiaalse orientatsiooni" kandja ning kanaliseerija; kui "taju verbaliseerija", mis eeldab "sotsiaalselt tähendusrikast tegevust" ja "tähenduse sotsiaalset karakterit" (Vygotsky 1978: 25-33, 37, 86, 90).

Nõnda on n-ö jutustuslike lünkade ning mitmelaadsete vasturääkivuste hulk, ulatus ja omavaheline läbipõimuvus - iseäranis just kontsentratsiooniga narratiivsete persoonide oletuslik-spekulatiivsele toimimisele - mõistagi ülimalt varieeruv. Nii keskendub Dave I juba kaks päeva hiljem (vt näidet 2) hoopiski tõigale, et Jesse'i ritsiinisigaretiga suitsupakk võidi viimase püksitaskus lihtsalt ümber vahetada, mistõttu näikse justkui edenduvat eeldus, et pigem oli mürgitamiskatse taga mingil moel Walti ja Jesse’i ülemus, maffiapealik Gus Fring, mitte lapse enese eksimus. Taas on Dave I narrtsepti inspiratsiooniks kaasaarendavad kaasvestlejad, seekord Fred. Täpsemalt tõukub Dave I kirjutatu omamoodi n-ö pehmest lahkarvamusest tema ja Fredi vahel.

\section{Näide 2}

Fred, võib-olla on sul õigus. Kuid parasjagu, kuni/kui nad ei näita, kuidas see võimalik oli, ei usu ma, et Huell oli võimeline ritsiinisigaretti välja kaevama ilma tervet pakki VÕTMATA või [just] seda võtta ja seda kuidagi Jesse’i taskusse tagasi libistada, ilma et ta märkaks. See oleks parajalt ponks trikk isegi Houdini jaoks. Otse öeldes, "A-rühm” POLE selleks võimeline. Pluss, pole võimalustki, et Saul seda teeks. Vähemalt mitte juhul, kui ta plaanist teaks, ja ma olen üsna kindel, et tal oleks küsimusi, enne kui ta nõustuks [sellise] taskuvarguse [plaaniga] läbikompamise ajal, kui Jesse on tulnud oma raha järele. Saul juba põgeneb uppuvalt laevalt. Kas ta tõesti riskiks Gusi vihastamisega kas siis viimase peamiselt kokalt varastades VÕI, vähemgi veel, võttes osa plaanist, mis lõppkokkuvõttes sunniks Jesse't olema kaasosaline Gusi tapmises? Tema [Gusi] peamine prioriteet on ellujäämine. Isegi kaudsed asjad, mida ta teinud on, lihtsalt et aidata Waltil \& Jesse’il elus püsida, on ta väga närviliseks teinud. Ei, juhul kui Walt oleks seda teinud, usuksin ma, et ta tegi seda ilma Saulita ja ma kohe kindlasti ei usu, et Huell oli piisavalt nobenäpp, et üht tagurpidi keeratud sigaretti Jesse’i taskust selle umbropsu sooritatud läbikompamise ajal välja libistada.

(Dave I, http://uproxx.com/sepinwall/breaking-bad-end-times-anappropriate-reponse/, 5.10.11, 3:07PM) 
Ma arvan, et Walt mürgitas Brocki. Mitte vahetult, aga Sauli kaudu. Sel ajal kui Huell Jesse üle vaatab või midagi, võis Saulil olla ligipääs sigareti juurde. Saul külastab teda [Jesse'it] iganädalaselt või nii ja temagi on omadega põrgus ning tahab kõigest sellest välja saada. Alguses, [selles] stseenis revolvriga, viimase asjana osutab revolver ühele taimele ja ma arvan, et Walt pü̈̈dis Brocki kaudu Jesse’ini jõuda ja teda Gusi vastu keerata (nii nagu Gus Jesse’iga tegi). Ma ei tea, kas Saul (või “A-rühm” oleks selliseks asjaks võimeline). Ja see, kuidas Gus rääkis Jesse’iga haiglas... näib, et tal pole sellega mitte mingit pistmist. Võib-olla Walt (kui meenutada, et revolver osutas taimele) valmistas sellest uue mürgi, mis pole aga eluohtlik, ja ritsiin [iampull] on endiselt sigaretis, ehkki praeguse seisuga ei tea me, kus see [sigarett] on. See aga panebki Jesse’i uskuma, et Walter mürgitas Brocki (nii Walt seda kavatseski), misjärel [Walt] seletab, et see polnud tema, vaid Gus. Aga me saame alles järgmises osas teada (kui see paljastab midagi).

(Fred, samas, 5.10.11, 2:20 PM)

Dave I tähelepanu on siin koondatud kolmele omavahel seotud elemendile: (a) tema täielik umbusk, et Walti ja Jesse advokaadi Sauli ihukaitsja Huell oleks ülepea füüsiliselt suuteline peaaegu mustkunstnikulaadset oskust nõudvaks täppistegevuseks; (b) kui tõesti ilmneb, et midagi sellist tõepoolest leidis aset, on tegemist siiski millegi täiesti võimatuga, kui just "nemad [s.o stsenaristid] ei näita, kuidas see võimalik oli”; ja lõpuks (c) tõmbab Dave I oma narrtsepti konkreetsemalt sisse mitte üksnes Huelli, vaid ka Sauli kavatsemisilma, põhjendades, et oletatav skeem, mille kohaselt kõige võti on sigaretipaki vahetus, ülepea ilma Sauli teadmata, n-ö ilma temapoolse "kaasamängimiseta", ei toimikski; ja et "pole võimalustki", et teda oleks võinud kuidagi nõusse saada.

Mis puudutab konkreetselt narratiivse persooni Sauli kavatsusilma ühistoimelist kaasarendamist mõnevõrra laiemalt, pakuvad märkimisväärset sisulist täiendust (eeskätt seoses Sauli oletatava valmiduse või mittevalmidusega "plaanis" osaleda) näiteks Sinistersilkmerchanti ja Paukeri narrtseptid (vt näidet 3), mis ei pärine enam sugugi Uproxxi netikeskkonnast, vaid hoopis samaaegsetest vestlustest Redditi foorumis, viies nõnda "temporaalselt põrkuvate" (temporal collision) ja sisuliselt seotud ühistoimeliselt kaasarenduvate aruteludeni. Nii pakuvadki alljärgnevad narrtseptid Redditi foorumist mõttelist jätku Uproxxi omadele, kuna need arendaksid justkui edasi Sauli kavatsemisilma. Nii nendib Sinistersilkmerchant, et kui pidada silmas Sauli tungivat vajadust põgeneda, võis Walt “öelda mida tahes" ja sundida Sauli “plaanis” n-ö oma osa mängima; mistõttu Saul ka nõnda korraldas, et just Huell oma väidetavaid taskuvargaoskusi rakendada sai. 


\section{Näide 3}

aga KUIDAS? jesse'il oli sel hommikul tööle minnes sigarett olemas. ta kohtas walti alles pärast, kui oli avastanud, et brocki on mürgitatud. waltil polnud võimalust sigaretile [ligi] saada. muidugi oleks ta brocki võinud uue ritsiinilaariga mürgitada, aga kadunud sigarett on kriitiline kild [, mis seda kinnitaks].

(Pauker, Reddit: https://www.reddit.com/r/breakingbad/comments/ kyw1d/episode_discussion_s04e12_end_times_spoilers/?sort=old, 3.10.11, 03:30:45UTC)

Huel tegi seda läbikompamise ajal. See, et Saul tungivalt Jesse'ile helistas (kuus korda!) ja nõudis, et [Jesse] tema kontorisse tuleks, oli tegelikult selleks, et sigaretid kätte saada. Walt võis Saulile öelda mida tahes, et põhjendada, mispärast paki väljavahetamine oluline on ja Saul oleks sellega kaasa läinud. Pean silmas seda, et miks muidu näidata Jesse’it Sauli väljumisstseenis? See, et tegelaskuju nagu Saul Goodman otsustab “ära kaduda” jätab sedavõrd palju ruumi loominguliseks koomiliseks pingelõdvenduseks [comic relief], aga selle asemel antakse meile see tobe läbikompamine (miks Jesse enda juurde kutsuda, kui kardad, et ta tuleb sind ära tapma?) ja harilik vestlus ("nooh... las ma annan sulle kõik su raha...”. Ilmselgelt juhtus see stseen just sellisel moel, et me hiljem mõistaks, et Walt maksis Saulile, et see Jesse'i sigaretid välja vahetaks. (Sinistersilkmerchant, samas, 04:08:45UTC)

Ei, ta vahetas ühe paki teise vastu. Mispärast on nii raske ette kujutada, et midagi sellist juhtub? Mustkunstnikud sooritavad käteosavustrikke, mis on päriselt jälgiva ja selliseid asju ootava publiku ees hulka keerulisemad. Taskuvarastel on sarnane oskus. Ja nagu me teame, siis meeldib Saul Goodmanile palgata mitmesuguste praktiliste oskustega inimesi. Ja kui juba Huellist rääkida, siis ma kahtlen, et Saul Goodmani “ihukaitsja” on idioot. Arvan, et Saulile on Huell äärmiselt kasulik just nimelt seetõttu, et inimesed tavatsevad seda tüüpi alahinnata. Ta näib olevat juhm, kohmakas ja letargiline. Aga päriselt pole ta ilmselt midagi neist. Samuti, šüžeevahendina oli see, et Saul Jesse’it “asjadega kurssi viis” tarbetu. Jesse kuulis kogu lugu detailselt Walti vaatenurgast, kui ta [Walti] tema majja tapma läks.

(Sinistersilkmerchant, samas, 04:35:18UTC) 


\section{3. Ühistoimeliselt kaasarenduv loominguline rahvakeel, pärisustamine, narratiivne persoon ja teisekogemus}

[Ü]ksnes dialoogiline ja osaluslik orientatsioon võtab teise isiku diskursust tõsiselt ja on suuteline sellele lähenema kui semantilisele positsioonile ja teise vaatepunktile. Üksnes sellise seesmise dialoogilise orienteerituse kaudu leiab minu diskursus end lähedasest kontaktist kellegi teise omaga, ühtaegu selles sulandumata, seda alla neelamata ja endas lahustumata teise tähendusjõudu, seega ainult nii saab ta diskursusena täielikult säilitada oma iseseisvust.

(Bahtin 1984: 64 (minu tõlge inglise keelest); vrd Sorokin 2016)

Antud alaosa eesmärk on uurida, kuidas eelnevalt illustreeritud narratiivsete tegelaskujudega suhestumisega seonduva netivestluse diskursiivsete operatsioonide ja strateegiate pinnalt oleks võimalik jõuda väärilise teooriani. Ühistoimeliselt kaasarenduvale loomingulisele rahvakeelele kui narratiivse põhialusega tähendustamisele on minu nägemuse kohaselt omased vähemalt kaks omavahel tihedalt seotud aspekti. Esiteks tõukuvad tegelaskujudega suhestuvad digitaalsed vestlussituatsioonid vaikimisi argitarkuslikest, tavakeeleliselt väljendatavaist "kogemusdeskriptoritest" (Turvey 2003: 433jj; vrd Turvey 2006: 118). Sellised igapäevakeele kaudu väljendatavad kogemusdeskriptorid on omakorda ajendatud teatavat laadi kontseptuaalsest mõtlemisest, mis on samuti argitarkuslikult orienteeritud. Siia haakubki mu käsitlus pärisustamisest, kuna rahvakeel, või täpsemalt teataval viisil orienteeritud keelekasutus, aitab konkreetsemalt piiritleda, mis üleüldse on kaalul, kui räägitakse tegelaskujude (tajutatavast) "kombatavusest" (tangibility), "tuttavlikkusest" (familiarity), "ligidusest" (proximity); ja kasvõi isegi neist kui "salasõpradest" (secret friends) (vt nt Plantinga 2011; Giles 2010; Fernyhough, Cit Lea 2017). Väga üldistatult saakski tõepoolest öelda, et siit johtuvad ka mu pärisustamise kontseptsiooni järelmid. Pärisustamine tähistab seega diskursiivset "päriseks tegemist" või (kui siinkohal luua uus eksperimentaalne mõiste) "pärisusloomet” (realmaking), mida rakendatakse kogukondliku arutelu hõlbustamiseks.

Seega, kui siinkohal vaidlustada lähtekoht (contra, inter alia, Smith 1995, 2011; Carroll 1990), et niihästi film kui ka teleseriaal kutsub esile kogemusi, mis pole "tegelikult päris", vaid millede puhul on tegemist reaktsioonidega pelgalt mõttes kantavatele "muljenditele ja ideedele" - s.t vaataja reageerib juba n-ö teise astme representatsioonile (vt ka Sorokin n. d.) - tuleks kriitika vormistada sotsiaal-materialistlikust vaatenurgast lähtuvalt. Ehk siis, oleks 
ju üsna absurdne mõelda, et tegelikes tingimustes (nt digimateriaalses vestluskeskkonnas) narratiivse kogemuse (reflektiivne) edasiandmine kulgeks järgnevalt: "minu mõte kurvastusest, mida ühe suurepärase tegelaskuju surm minus tekitas, kurvastas mind" (Sorokin 2018a: 110). Antud küsimust nii käsitledes tuleks üksnes nõustuda filmiteoreetik Malcolm Turvey'ga, kes on tõdenud, et "sääraste teooriate [poolt loodava] vaataja algtüüp oleks otsekui pime filmi kui sellise suhtes" (Turvey 2003: 433jj).

Nii tõukuvadki minu pakutava lähenemise alusväited eeldusest, et "fiktsionaalsete olevuste" kui narratiivsete persoonide olemasolu (presence) on tajutav ja narratiivselt edastatav otseselt, selmet kahelda viimase tõepärasuses; selmet konstrueerida mingisugune müstifitseeritud teadvussõltuvuslik vahepealne (mõtte)ruum. Sõnadel "reaalsus", "väljamõeldis", "fakt” jne puudub käesoleval juhul sisuline kaal, sest tavalised inimesed ei nihku oma mõtlemises ja aruteludes ebamäärasesse, abstraheeritud projitsiooni reaalsusest, kui käepärasem ja loomulikum juba on olemasolev reaalsus, mille põhjal, millest kui intuitiivsest "mateeriast" tulenevalt (iseasi, mis piirini) tähendustamistegevus toimub.

Ja tõepoolest; kui põigata korraks tagasi olemasolu küsimuse juurde, siis õigupoolest on Malcolm Turvey soovitanud antud mõistele ka tänuväärse verbivormi, s.o olemasolu kui end olemasolustav (presence-ing, presenc-ing itself). Tuginedes Ludwig Wittgensteini käsitlusele partküüliku joonistusest (vahel näed küülikut, vahel parti, ent mitte kunagi mõlemat korraga), vaagibki Turvey:

[S]ee [et näha kujutist kas pardi või küülikuna] pole meie mentaalse tegevuse, kujutlusvõime, või tõlgendamisega kaasneva vaimse tegevuse [mental activity] saadus. Pigem, [kujutise nägemine küülikuna; seeingas rabbit] on miski, mis näib end olemasolustavat [presence itself] või ilmsiks tulevat [emerge] vaatluse all olevas figuuris sõltumatult selle vaatlejast; ja just sel põhjusel kirjeldame antud visuaalset kogemust nõnda, justkui oleks figuur ise fü̈̈siliselt muutunud, seega [me] omistame sellele toimijalikkuse [agency]"

(Turvey 2003: 452; rõhutused ja allajoonitus lisatud; minu tõlge - S. S.).

Ehk siis lühidalt: selleks, et mingisugust kujutatut (depictured) tähendustada, peab see esmalt olema omas olemasolus avastatav, tuvastatav (discoverable, recognizable) (vrd nt Casebier 1991).

Teiseks oluliseks ühistoimeliselt kaasarenduvale loomingulisele rahvakeelele omaseks aspektiks on see, et argiselt koordineeritud keelepruugil on kalduvus "insaiderlikuks kiirsuhtluseks" (insider shorthand), millele uurija (kui n-ö väljaspoolt tulija), seda täiel määral hoomamata, ei pruugi isegi osata tähelepanu pöörata. Miks? Sest n-ö väljastpoolt sisse vaadates on vajaka teatav ajaloolis- 
narratiivne teadmuslävi. Nii võib mõni netisuhtluse napp vestlusfraaski olla analüütilisel tasandil mõtestatav väljaarenduva rahvanarratiivina, milles võivad sisalduda mitte üksnes sügavuti kontekstuaalsed mõttearendused (seoses narratiivse kogemusega), vaid ka tähelepanuväärsed arengud seoses mitmetasandiliselt saamisesoleva (Sorokin 2017) loojätkuvusega kogukondlikul tasandil. Ainuski kogukondlik üksiktekst kui narrtsept (s.o kommentaaritekst või foorumipostitus) ei paikne ju vaakumis. Ehkki see tähelepanek ei pruugi olla just eriti uudne, iseäranis folkloori kontekstis laiemalt, väärib see esiletõstmist, kuna aitab selgitada, mispärast on seoses populaarsete televisiooniseriaalidega kogunenud mahukas netimaterjal tekitanud meediauurijates pigem pealiskaudset ja üldistavat huvi, selmet välja töötada kontekstitundlikult rakendatavaid mõisteprotokolle vastavaks lähianalüüsiks nagu illustreeritud alaosas 1.

Kui nüüd eelöeldust lähtudes siduda omavahel ideed kogemuslikest (argitarkusel põhinevaist igapäevakeele) deskriptoritest ja eelpool illustratiivse analüüsi teel näitlikustatud empiirilisest ainesest, oleks seniöeldule veidi lisatausta pakkudes võimalik möönda üheskoos filmifilosoof Carl Plantingaga, et: "Enamikule vaatajatest ... on interaktsioon tegelaskujude "kui persoonidega" narratiivse meedia [narrative fiction] puhul peamiseks mõnuallikaks" (Plantinga 2011: 40; rõhutus lisatud). Ka meediapsühholoog Christoph Klimmt on tähendanud, et "enamasti on meelelahutusliku meedia keskmes inimesed" (Klimmt jt 2006: 29; rõhutus lisatud). Nõnda ilmneb, et senikäsitletud argitarkusliku lähenemise saab piiritleda suunatud huvina narratiivses meedias kujutatud teiste inimeste kui inimeste vastu. Nii jõuame tegelaskujudega suhestumise uurimisel välja $\mathrm{nn}$ inimhuvi (human interest) lähenemiseni, mis jääb sisuliselt väga kaugele pelgalt abstraktsest, ülevalt-alla "vandlitorni" teoretiseerimisest.

Sellest johtuvalt saab omakorda võimalikuks väita, et diskursiivses vestlusprotsessis sellest, kuidas televaatajad-vestlejad tähendustavad (make sense of) narratiivseid tegelaskujusid kui persoone, näib olevat talletunud teatav päriselulisuse, igapäevaelu "sete" (uudishimulikud lapsed, oskuslikud taskuvargad, inimeste suitsetamisharjumused jpm). Just säärasest päriselujäägist kasvõi vaikimisi lähtumine, selle olemasolu üleüldse, võimaldabki "fiktsionaalse" kogemuslikkuse mõtestamist just nimelt igapäevase argitarkuse kaudu. Ehk teisisõnu: käesolevas seoses kohaseim teooria peab suhestuma välispidiste (externalist $)^{14}$ sotsiaalse kognitsiooni vormelitega, nii nagu neid igapäevaelus rakendatakse. Sellised vormelid võivad enamasti avalduda teatava "keelematerialismina"15_ s.t "päris elu keelena" (Sprache des wirklichen Lebens) "ühises kollektiivses eesmärgipärases tegevuses” (D’Alonzo 2018: 1, 7; vrd Thao 2009; Sorokin 2018c). Eelkirjeldatud kalduvus tuleneb eeskätt vajadusest kindlustada "fiktsiooni" lihtne mõistmine. 
Eelöeldut arvesse võttes on võimalik väita, et ka "fiktsionaalsed" suhestumised tõukuvad väga oluliselt keele kommunikatiivse kasutusväärtuse sotsiopragmaatikast (vrd Jucker \& Locher 2017: 1-2, vt ka 5-7). Kui nüüd eelneva ideestikuga lõpuni minna, võiks väita, et narratiivse tegelaskujuga suhestumine oleks ümberkujundatav fiktsiooni/de "materialismi" või fiktsiooni/de "materialiseerimise" teel. Lühidalt: viimatimainitud kontseptsioonid aitaksid arendada teoreetilist arusaama rahvakeelest, mis on objektiivse reaalsuse suhtes jaatav, rajades objektiivse reaalsuse normatiivse olemasolu ja fiktsiooni vahele piirme, ehkki võib-olla ebausaldusväärse (slippery[-]nature[d]; samas: 3). Nõustudes soveti Venemaa lingvisti Valetin Vološinovi ideega võiks käesoleva alaosa põhipostulaadid kokku võtta järgnevalt: "Kognitsioon raamatute ning teiste inimeste sõnade suhtes ning kognitsioon omaenese peas kuuluvad samasse reaalsusse, ja erinevused, mis on pea ja raamatu vahel, ei mõjuta kognitsiooni sisu" (Vološinov 1973: 34).

\section{Kuidas selgitada positiivset tegelaskujuontoloogiat paradoksaalsele jänesele, ehk: alternatiivne teoretiseerimine vastamisi järjekindlate idealistlike truismidega}

Pean silmas hüpoteesi, et tajutav [perceptible] on üksnes see, mis asub meeles, mis tajutavat tajub: et tegelikult ei taju me väliseid asju, vaid üksnes meelele jäädvustunud [imprinted upon the mind] kujutisi ja pilte, mida kutsutakse muljenditeks [impression] ja ideedeks.

Kui see tõsi oleks: eeldusel, et teatavad muljendid ja ideed mu meeles eksisteerivad, ei saa ma nende olemasolu põhjal järeldada mitte ühtegi muud asja [any thing else]: minu muljendid ja ideed on ainsad eksistentsid, millest minul on teadmine ja kontseptsioon: ja need on nii põgusad ja ajutised olemasolud, et neil ei saa olemasolu ollagi, sest nad püsivad ainult senikaua, kuniks mina neist teadlik olen. Sellise hüpoteesi kohaselt kogu universum minu ümber, kehad ja hinged, päike, kuu, tähed ja maa, sõbrad ja tuttavad, eranditult kõik, mille eeldasin olevat alaliselt olemasoleva, mõelgu ma siis neist või mitte, haihtuvad jalamaid [...] Ma ARVASIN, et [selline hüpotees] on mõistusevastane [.]

(Thomas Reid, An Inquiry into the Human Mind, on the Principles of Common Sense (1819), lk xiii-ix (rõhutused ja suurtähestus originaalis; minu tõlge - S. S.)) 
Senine diskussioon on käsitlenud vastuolu, kuidas tänapäeva teaduslikud lähenemisviisid on keskendunud niihästi fiktsionaalsete kui ka pärisinimeste kogemise mõtestamisele. Siinkohal pean mõistagi silmas selliseid kontseptsioone nagu simuleerimine, transportatsioon, immersioon ning teise mentaalne representeerimine laiemalt (Ryan 2001; Goldman 2006; Shanton \& Goldman 2010; Gerrig 1993; Walton 1990). Seal, kus praktiline alt-üles ehk rahvalik narratiivse kogemuse tähendustamine haakub otsekui loomulikult ja iseeneslikult käsitlustega sotsiaalsest jagatud kogemusest; takerduvad säärased "teaduslikud" ülevalt-alla käsitlused teoreetilisse abstraheerimisse ja justkui müstifitseerivad retseptiivset kogemust, sest nad näevad selle asuala rangelt üheainsa kogeja kujutlusvõime piirmeis, n-ö individuaalse ego "tõeriigis" (vrd Meskin \& Weinberg 2003).

Paratamatult eraldavad sellised seespidised (internalist) lähenemised teo (kogemise) kontekstist (see, mida kogetakse; see, millele kogemine on suunatud, olenemata esitusmeediumist). Sellega võib kaasneda ka keele ja sõna kui sotsiaalse elu elementaarosiste alahindamine. Seespidises käsitluses muundub keel, kui rakendada siinkohal Henry McDonaldi kõnekat fraasi, "eeterlikuks", sest kõik taandatakse "säärasele ettekujutusele fiktsionaalsest lugemispraktikast, kus romaani kätte haaranu teostab fenomenoloogilise reduktsiooni ... paigutab 'päris maailma' sulgudesse ... ja ... sukeldub teise, fiktsionaalsesse maailma" (McDonald 2001: 40-41). Kuid on see alati nõnda, või täpsemalt: peaks see analüütilis-teoretiseerivalt mõeldes alati just nii mõtestatav olema?

Tuues välja paralleele päriselulise sotsialiseerumise ja fiktsionaalsete tegelaskujudega suhestumise vahel, möönab kultuuriantropoloog John L. Caughey, et "võbelevaid kujutisi [teleriekraanil] tabatakse [apprehend] ${ }^{16}$ olulisel määral kui inimesi" (Caughey 1984: 36, 40; rõhutus originaalis). Kui nüüd küsida, mil moel senist teoretiseerimist põhjendada, võiks vastata, et materiaalsed, s.o päriselulised sotsiaalsed suhted ning interaktsioon kui selline leiavad - ülekantuna tegelaskujudega suhestumisse või täpsemini tegelaskujudega suhestumine ülekantuna päriselulistesse sotsiaalsetesse suhetesse ${ }^{17}$ - oma võrdkuju (para) sotsiaalses, mille keskmes on narratiivselt arendatud, "pärisloodud” (realmade) sotsiaalsete sidemete (social bonds) tajutavus.

Käsitluse "parasotsiaalsest interaktsioonist" töötasid välja 1950. aastate ameerika psühhiaatrid Donald Horton ja R. Richard Wohl, kes analüüsisid televaatajate suhestumist nn ekraaniinimestega nagu uudisteankur, saatejuht jmt. Tänapäeva meediapsühholoogias ja mujalgi on käsitluse mõjupind juba ammu laienenud igasugustele "meediafiguuridele" (Horton \& Wohl 2006; vt nt Giles 2002, 2010; Wulff 1992, 2006). Seega pakub ka käsitlus parasotsiaalsest interaktsioonist omajagu veenvat panust, aitamaks mõtestada televaatajate- 
vestlejate ekspressiiv-narratiivset püüdu mõista n-ö ekraaniinimesi otsekui kombatavate "teistena". Inimestena, kes võivad küll olla kogejaga "sarnased", kuid siiski määratletud kindlapiiriliselt suveräänsete, omas-maailmasiseseisvalt-eksisteerivatena (vrd Alderson-Day \& Bernini \& Fernyhough 2017; Plantinga 2011; Goldie 2004; Vaage 2014; Blanchet \& Vaage 2012).

Siinkohal siis tulebki mängu narratiiv kui keele argitarkuslik-loominguline "tööriist", mis tõukub - olgugi, et räägime vaid narratiivse kogemuslikkuse tähendustamisest - ülimalt kontekstitundlikust sotsio-ajaloolis-praktilisest dimensioonist (vrd Herman 2013; Hutto 2007, 2008; Vygotsky 1978, 1986; Voloshinov 1973).

Eelkirjutatust tulenevalt, iseäranis kui pidada silmas senist diskussiooni, näen ma ühistoimeliselt kaasarenduva loomingulise rahvakeele 'mootorina' või fundamentaalprintsiibina sotsiaal-materialistliku suunitlusega tähendusloomepraktikat kui sellist (ehk pärisusloomet). Teisisõnu: pärisusloomest saab teatav narratiivne praktika, mille juures on määrav - eriti kui silmas pidada kogukondlikku diskursust -, et ka narratiivsele teisele, sarnaselt päriseluliste “inimeste lugudega" (Goldie 2004), lähenetakse n-ö kolmanda isiku tasandilt. Tema kohta teadaolevat ning eeldatavat informatsiooni püütakse ühitada tema laiema (elu)konteksti ja (elu)ajalooga (kuid ka kogeja enda omaga). Ehk siis, selmet mõelda, "mida teeksin mina, kui oleksin tema" (simulatsioon) või "mida teeksin mina, kui mina elaksin tema maailmas" (transportatsioon, immersioon), püütakse tedagi pärisusloovalt mõtestada ajalooliselt - “ajalooks" on siin lihtsalt ajapikku temast kui persoonist kogunenud narratiivne teadmus.

Siit tuleneb omakorda terve rida küsimusi. Mida ja kuidas võiks see persoon teha ja käituda? Kuidas ja kas on tema eeldatav toimimine üleüldse kooskõlastatav sellega, mida võivad välja pakkuda või mida on välja pakkunud narratiivse maailma loojad, stsenaristid? ${ }^{18}$ Ja nii edasi.

Kogu senikäsitletud keeruka dünaamika hoomamiseks pakkusin oma doktoridissertatsioonis välja mitmekesise eksperimentaalse mõisteaparatuuri. Pidades silmas senist arutelu, sobiks mu väitekirja peamist väidet kokku võtta vahest järgnevalt:

Seriaali üle arutlejate (ratsionaalne) kriitikameel - s.o teadmine, et tegemist on väljamõeldisega, et nad ei jälgi päris sündmusi reaalajas - kaugeltki ei seisatu. Fiktsiooni kogemise juures laiemalt ning tegelaskujudega suhestumise juures kitsamalt ei seadistata reaalsust "pausile", vaid vastupidi, televaatajatevestlejate individuaalne ja sotsiaalselt jagatud kogemuslik (väline, indiviidist sõltumatult eksisteeriv) reaalsus kujuneb tähendusloome, või siis vahest täpsemini väljendudes pärisusloome juures instrumentaalseks. 
Siinjuures oleks aga paslik märkida, et simuleerimise jt mõistmispraktikate kohatist rakenduslikku vajalikkust - kuigi just kohatist ja kindlasti mitte universaalset - ma üldse ei välista. Sellegipoolest seab minu empiiriline analüüs põhjendatud kahtluse alla sääraste strateegiate heuristilise väärtuse kogukondlikus, antud juhul siis netisuhtluses. ${ }^{19}$ Samavõrd näib sotsiaalselt sidusa diskursuse aluseks olevat ka arutluse all olevate inimeste argitarkuslik käsitamine sotsiaalsete eksistentsidena, kes, olenemata esitusmeediumist või objektiivsest reaalsusest, sõltuvad ümbritsevatest suhetest. Nagu märgib antud seoses ökoloogiline filmiteoreetik Joseph D. Anderson: "Me peame tajuma tähendusi seoses kellegagi, tegelaskujuga filmis, kes asustab [inhabits] filmi fiktsionaalset maailma, on allutatud selle piirangutele ja võimalustele [affordances]" (Anderson 1996: 136-137).

Ehk siis: omas maailmas seda asustavana eksisteeriv narratiivne persoon asub selles suveräänsena; ta on selle maailmaga koos (vastupidiselt tegelaskuju mõtestamisele ühe kavatsuslikkust mitte omava "mutrikesena" teatava narratiivse terviku sees). Eeltoodust johtubki minu väide, et seoses narratiivsete persoonidega on teleseriaali "Halvale teele" vaatajad-kommenteerijad teisttajuvad (perceiving $\underline{\mathrm{AT}}$ ), mistõttu nad ka räägivad neist $\underline{\text { kui }}$ teistest, kelle elud neid järk-järgult neelavad; ja mitte, kelle eludesse nad neelatud saavad (absorbed BY contra absorbed "in"; vt ka Sorokin 2016a, b; Sorokin n.d.).

Eelöeldust tõukuvalt saab seega öelda, et vestlussituatsiooni tasandil näib range eristus "fiktsionaalne" versus "päris" (inimene) olevat sisuliselt tühine. Sellegipoolest näib käibivat eeldus, nagu oleksime selliste igapäevakujut(1)uste puhul silmitsi paradoksiga. Kuna üldjuhul näikse karakteriga suhestumise teoretiseerimine eelistavat kitsalt kogejapõhist või pigem individualistlikku teadvussõltuvuslikku (mind-dependent) valemit. Ja siit siis ka eelnimetatud käsitlused fiktsionaalsesse maailma transporteerumisest, fiktsionaalse teise simuleerimisest enese peal/peas jne. Nii otsustasingi omalt poolt välja pakutava mõisteraamistikuga leida äsjakirjeldatud vastuoludele kohast kompromissi, heites kahtlust egokeskse narratiivse kogemuslikkuse piisavusele, seda iseäranis kogukondliku ja pikaajalise diskursusepraktika perspektiivilt vaadelduna.

\section{Kokkuvõtteks}

Lõpetuseks sobiks veel kord küsida: mida pean silmas, rääkides pärisustamisest? Mõiste inspiratsiooniks on ingliskeelne neologism "realitization" (toortõlkes "realitiseerimine"), mida sõnastik määratleb kui "kellegi reaalsusse toomise akti". ${ }^{20}$ Teisisõnu, pikaajalised sarikohtumised narratiivsete persoonidega, 
sellest tulenev nendekohase teadmuse pidev rikastumine (s.o nende narratiiv-ajalooline "elu-ajalugu") ja lõpuks interneti poolt võimaldatav järjepidev kogukondlik diskussiooniruum - need aspektid, võetuna ühtse tervikuna loovad ainulaadse pinnase selleks, et pelkadest tegelaskujudest teleriekraanil edeneksid välja narratiivsed persoonid, kuna neid tajutakse eeskätt just suveräänsete "arutlevate toimijatena" (reasoning agents). Mil moel säärane tajumine aga avaldub? Laias laastus võtabki kontseptsioon pärisustamisest kokku seniräägitu:

(i) televaatajate-vestlejate keelekasutus on narratiivselt "seadistatud" (narratively tooled);

(ii) narratiivsed implikatsioonid tingivad keele loomingulisi impulsse, pannes nii aluse esmasele, elementaartasandi mõistmisloogikale; s.t narratiivseid persoone tunnustatakse (acknowledge) argitarkuslikult (commonsensically) päriselt ja suveräännselt koos oma maailmaga olevatena (contra "mutrikestena" selle maailma täiteks); ehk siis: saaksime rääkida tegelaskujude kui narratiivsete persoonide eksistentside jaatamisest - positiivsest (karakteri)ontoloogiast (affirmative ontology) (vrd Sorokin 2018c);

(iii) "päris" ei ole antud seoses mõeldud antiteesina "fiktsioonile", vaid jätkuna huvile teiste inimeste vastu, olenemata esitusmeediumist.

Kui juhinduda seniöeldust, kuid püüdes kokku võtta ka käesoleva artikli keskseid väiteid, siis pidades silmas ühelt poolt minu kontseptsiooni ühistoimeliselt kaasarenduvast loomingulisest rahvakeelest ja teisalt käsitlust vaikimisi praktiseeritavast pärisustamise aktist, võiks seda teha järgnevate tähendustamiselementide kaudu, millest tõukub televaatajate-vestlejate tähendustav pärisusloome (vrd Sorokin 2018a: 34-35):

1. Nad uurivad üksipulgi narratiivsete persoonide "kavatsuslikke välju" (intentionale Feld, Wulff 2006), s.t viimaste "elude ajalugusid" ja suhtestusümbrust (relational surroundings), kantuna omakorda kavatsusest mõista narratiivsete persoonide lugusid "õigesti", seetõttu eranditult alati domineerivat autorijutustust "läbi sõeludes" (sieving), püüdmaks avastada vähimatki võimalikku eksimust;

2. nad püüavad maksimaalselt "parandada" näilisi ja tajutavaid ebakõlasid ja katkestusi, taotledes seejuures võimalikult laialdast kontekstitundlikku "selgituslikku sidusust" (Thagard 2000). Sealjuures pööratakse tähelepanu, tõlgendatakse, täiendatakse ja teisendatakse narratiivsete persoonide situeeritud "suuremate narratiivide" "tihedaid kirjeldusi" (Geertz 1973); 
3. selmet näha iseennast narratiivse persooni asemel või tema maailma “ümberkantuna" - lähenemised, mis õonestavad narratiivsete persoonide (tajutavat) suveräänsust ning seega on vastuolus punktiga 1 võivad teleseriaali üle arutlejad teatavail tähendustamishetkil jõuda narratiivsete persoonide elukontekstide ja arutlejate endi elukonteksti ühildamiseni. Seda määratlesin oma doktoriväitekirjas kui päris ja (tajutava) elukogemuse loostatud kokkukäändumist (twistory) (vt Sorokin 2018a: 34-35, 72-76);

4. nad jäävad sõltuvaks laiemast diskussioonisfäärist (vastastikku seotud vestlusruum mitmesugustes blogi- ja foorumikeskkondades), mistõttu saab väita, et narratiivsed persoonid saavutavad agentsuse, tegijalikkuse, “toimimaks” kõrvuti ning kesksena selles sfääris, saamata sealjuures - ja see on üsna kriitiline punkt - n-ö kõrvaltvaatavates (onlooking) vaatajates "lahustatud" ja vastupidi.

\section{Kommentaarid}

1 Käesolev artikkel põhineb osaliselt mu ettekandel Eesti-uuringute Tippkeskuse ja 61. Kreutzwaldi päevade rahvusvahelisel konverentsil "Varieerumine keeles, kirjanduses, folklooris ja muusikas" (korraldajad Tartu Ülikool ja Eesti Kirjandusmuuseum, Tartu, 7.-8.12.2017). Olen tänulik inspireeriva ning mõtlemapaneva tagasiside ja kriitiliste tähelepanekute eest. Samuti olen väga tänulik toimetajale ja arvustajatele vajalike nõuannete ja paranduste eest käesoleva artikli eelmistes versioonides. Käesoleva artikli valmimist toetas teadusgrant PUT1481 "Imaginaarsete narratiivsete stsenaariumite roll kultuuridünaamikas"(1.01.2017-31.12.2020) ja Eesti-uuringute Tippkeskus (TK145). Vt ka Sorokin 2018b. Kõnealuste teemade käsitlust inglise keeles vt Sorokin (ilmumas).

${ }^{2}$ Alan Sepinwalli püsikolumn "What's Alan Watching?" Uproxx.comis (https://uproxx. com/sepinwall/breaking-bad-end-times-an-appropriate-reponse/; https://uproxx.com/ sepinwall/breaking-bad-face-off-say-uncle/); professionaalne tele- ja filmikriitika blogi "The A. V. Club" (https://tv.avclub.com/breaking-bad-end-times-1798169832; https:// tv.avclub.com/breaking-bad-face-off-1798169945); Tim Goodmani kolumn "The Bastard Machine" Hollywood Reporteris (https://www.hollywoodreporter.com/bastard-machine/ breaking-bad-spoiled-bastard-ep-243218; https://www.hollywoodreporter.com/ bastard-machine/breaking-bad-spoiled-bastard-season-246076) ja Redditi ala-reddit r/breakingbad (https://www.reddit.com/r/breakingbad/comments/kyw1d/episode_ discussion_s04e12_end_times_spoilers/; https://www.reddit.com/r/breakingbad/ comments/16j94/episode_pisscusion_s04e13_face_off_spoilers/). (Lingid vaadatud 22.12.2018; Hollywood Reporteris ei näi kommentaare enam arhiveeritud olevat).

3 Seriaali "Halvale teele" teoreetilisteks perspektiivideks vt nt Koepsell \& Arp 2012; Pierson 2014; Blevins \& Wood 2015.

4 The Revolution Was Televised. The Cops, Crooks, Slingers and Slayers Who Changed TV Drama Forever (Sepinwall 2012; täiendatud trükk avaldatud 2015). 
5 Vt https://uproxx.com/sepinwall/review-john-ridley-aims-high-with-abcs-americancrime/ (vaadatud 14.02.2019).

6 TwoP-ist lähemalt vt nt Gray 2005; Andrejevic 2008; Stilwell 2003.

7 "I did it for me. I was good at it. And I was really... I was alive" (https://www.youtube. $\mathrm{com} /$ watch? $\mathrm{v}=\mathrm{gUJ}$ ci5RWsqE).

8 Detailse ülevaate saamiseks sellest, kuidas ma käesolevat materjali analüüsieelselt töötlesin, vt Sorokin 2018a: 145-150.

9 Argitarkust (common sense) määratlen ma siinkohal 17. sajandi šoti argitarkusfilosoofist Thomas Reidist ja tema sensus communis käsitlusest inspireerituna (Reid 1819; vt ka Sorokin 2018a: 36n55).

${ }^{10}$ Kommentaaritekstide ja foorumipostituste kirjavahemärgid, suurtähestus jms on edasi antud muutmata kujul.

11 Siin ja edaspidi minu tõlge - S. S.

12 Tuleb märkida, et minu mõistekasutus pole siinkohal seotud Paul Werthi nägemusega (vt Werth 1999: 213jj).

${ }^{13}$ Käsitlust erinevatest ilmadest vt Sorokin 2018a: 134-144.

${ }^{14}$ Näiteks võiks väita, et sotsiaalkonstruktivistlik lähenemine sotsiaalsele kognitsioonile ähvardab langeda samasse ontoloogiliselt suletud ringi lõksu, kui seespidine (internalist) teadvusfilosoofia.

${ }^{15}$ Esimesena kasutasid seda mõistet Karl Marx ja Friedrich Engels oma "Saksa ideoloogias” (Marx \& Engels 1998: 42).

${ }^{16}$ Märkigem, et valisin tõlkeks sihilikult "tabatakse", kuna siinkohal tekib üsna selge paralleel eelkirjeldatud Malcolm Turvey käsitlusega.

17 Vt minu "ülekandemudeli" (Carry-Over Model) käsitlust, Sorokin (2018a: 51-67).

${ }^{18}$ Vrd Hafsteini (2014) "anti-autorlus" ja Howardi (2008) “alternatiivne autorlus" ehk siis: kaasarenduv kogukondliku pädevuse kasv.

19 Näiteks võiks käesoleva teoreetilise raamistiku paikapidavust testida ka päriseluliste raamatuklubide puhul. Antud viite eest olen erakordselt tänulik oma oponendile, prof. dr. Marco Caracciolole.

${ }^{20} \mathrm{http}$ ://nws.merriam-webster.com/opendictionary/newword_display_alpha. php?letter=Re\&last=20 (vaadatud 06.03.2019). 


\section{Kirjandus}

Alderson-Day, Ben \& Bernini, Marco \& Fernyhough, Charles 2017. Uncharted features and dynamics of reading: Voices, characters, and crossing of experiences. Consciousness and Cognition 49, lk 98-109 (doi: 10.1016/j.concog.2017.01.003).

Andrejevic, Mark 2008. Watching Television Without Pity: The Productivity of Online Fans. Television \& New Media 9 (1), lk 24-46 (doi: 10.1177/1527476407307241).

Anderson, Joseph D. 1996. The Reality of Illusion: An Ecological Approach to Cognitive Film Theory. Carbondale, Ill.: Southern Illinois University Press.

Bacchilega, Cristina 2015. Narrative Cultures, Situated Story Webs, and the Politics of Relation. Narrative Culture 2 (1), lk 27-46.

Bahtin 1984 = Bakhtin, Mikhail M. 1984. Problems of Dostoevsky's Poetics. Minneapolis: University of Minnesota Press.

Banks, John \& Humphreys, Sal 2008. The Labour of User Co-Creators: Emergent Social Network Markets? Convergence: The International Journal of Research into New Media Technologies 14 (4), lk 401-418 (doi: 10.1177/1354856508094660).

Blanchet, Robert \& Vaage, Margrethe Bruun 2012. Don, Peggy, and Other Fictional Friends? Engaging with Characters in Television Series. Projections 6 (2), lk 18-41 (doi: 10.3167/proj.2012.060203).

Blevins, Jacob \& Wood, Dafydd (toim) 2015. The Methods of Breaking Bad: Essays on Narrative, Character and Ethics. Jefferson, NC.: McFarland \& Company.

Carroll, Noel 1990. The Philosophy of Horror: or, Paradoxes of the Heart. New York: Routledge.

Casebier, Allan 1991. Film and Phenomenology: Toward a Realist Theory of Cinematic Representation. Cambridge: Cambridge University Press.

Caughey, John L. 1984. Imaginary Social Worlds: a Cultural Approach. Lincoln: University of Nebraska Press.

D'Alonzo, Jacopo 2018. Tran-Duc-Thao and the language of real life. Language Sciences 70, lk 1-13 (doi: 10.1016/j.langsci.2018.06.007).

Détienne, Françoise \& Barcellini, Flore \& Baker, Michael James \& Burkhardt, JeanMarie \& Fréard, Dominique 2012. Online epistemic communities: theoretical and methodological directions for understanding knowledge co-elaboration in new digital spaces. Work (Supplement 1), lk 3511-3518 (doi: 10.3233/WOR-2012-1036-3511).

Détienne, Françoise \& Baker, Michael James \& Vanhille, Mohini \& Mougenot, Céline 2017. Cultures of collaboration in engineering design education: a contrastive case study in France and Japan. International Journal of Design Creativity and Innovation 5 (1-2), lk 104-128 (doi: 10.1080/21650349.2016.1218796).

Fernyhough, Cit in Lea 2017 = Lea, Richard 2017. Fictional Characters make "experiential crossings" into real life, study finds (https://www.theguardian.com/books/2017/feb/14/ fictional-characters-make-existential-crossings-into-real-life-study-finds - 6. märts 2019). 
Geertz, Clifford 1973. The Interpretation of Cultures. New York: Basic Books, Inc., Publishers.

Gerrig, Richard J. 1993. Experiencing narrative worlds: on the psychological activities of reading. New Haven: Yale University Press.

Giles, David C. 2002. Parasocial Interaction: A Review of the Literature and a Model for Future Research. Media Psychology 4 (3), lk 279-305 (doi: 10.1207/ S1532785XMEP0403_04).

Giles, David 2010. Psychology of the media. Palgrave insights in psychology. Houndmills, Basingstoke, Hampshire, New York: Palgrave Macmillan.

Giles, David \& Stommel, Wyke \& Paulus, Trena \& Lester, Jessika \& Reed, Darren 2015. Microanalysis of Online Data: The methodological development of "digital CA". Discourse, Context \& Media 7, lk 45-51 (doi: 10.1016/j.dcm.2014.12.002).

Giles, David \& Stommel, Wyke \& Paulus, Trena 2017. The Microanalysis of Online Data: The next stage. Journal of Pragmatics 115 (Juuli), lk 45-51 (doi: 10.1016/j. pragma.2017.02.007).

Goldie, Peter 1999. How We Think of Others' Emotions. Mind \& Language 14 (4), lk 394-423 (doi: 10.1111/1468-0017.00118).

Goldman, Alvin I. 2006. Simulating minds: the philosophy, psychology, and neuroscience of mindreading. Oxford \& New York: Oxford University Press.

Gray, Jonathan 2005. Antifandom and the Moral Text. Televison Without Pity and Textual Dislike.American Behavioral Scientist 48 (7), lk 840-858 (doi: 10.1177/0002764204273171).

Hafstein, Valdimar Tr. 2014. The Constant Muse: Copyright and Creative Agency. Narrative Culture 1 (1), lk 9-48 (doi: 10.13110/narrcult.1.1.0009).

Herman, David 2002. Story Logic. Problems and Possibilities of Narrative. Lincoln ja London: University of Nebraska Press.

Herman, David 2013. Storytelling and the sciences of mind. Cambridge, Mass.: The MIT Press.

Horton, Donald \& Wohl, Richard R. 2006 [1956]. Mass Communication and Para-Social Interaction: Observations on Intimacy at a Distance. Psychiatry 19 (3), lk 215-229 (doi: 10.1080/00332747.1956.11023049 - digitaalne reprint aastast 2006, http://www. participations.org/volume\%203/issue\%201/3_01_hortonwohl.htm - 7. märts 2019).

Howard, Robert Glenn 2008. The Vernacular Web of Participatory Media. Critical Studies in Media Communication 25 (5), lk 490-513 (doi: 10.1080/15295030802468065).

Hutto, Daniel D. 2007. Folk Psychology without Theory or Simulation. Hutto, Daniel D. \& Ratcliffe, Matthew (toim). Folk psychology re-assessed. Dordrecht: Springer, lk 115-135 (doi: 10.1007/978-1-4020-5558-4_7).

Hutto, Daniel D. 2008. Folk psychological narratives: the sociocultural basis of understanding reasons. Cambridge, Mass: MIT Press. 
Jucker, Andreas H. \& Locher, Miriam A. 2017. Introducing Pragmatics of Fiction: Approaches, trends and developments. Locher, Miriam A. \& Jucker, Andreas H. (toim). Pragmatics of Fiction. Berlin ja Boston: Walter de Gruyter, lk 1-21 (doi: 10.1515/9783110431094-001).

Klimmt, C. \& Hartmann, Tilo \& Schramm, Holger 2006. Parasocial Interactions and Relationships. Bryant, Jennings \& Vorderer, Peter (toim). Psychology of entertainment. London \& New York: Routledge, lk 291-311.

Koepsell, David R. \& Arp, Robert 2012. Breaking Bad and Philosophy. Badder Living through Chemistry. Chicago: Open Court.

Marx, Karl \& Engels, Friedrich 1998. The German ideology: including Theses on Feuerbach and introduction to the critique of political economy. Amherst, N.Y: Prometheus Books. [Originaal 1846.]

Meskin, Aaron \& Weinberg, Jonathan M. 2003. Emotions, Fiction, and Cognitive Architecture. British Journal of Aesthetics 43 (1), lk 18-34 (doi: 10.1093/bjaesthetics/43.1.18).

McDonald, Henry 2001. Wittgenstein, Narrative Theory, and Cultural Studies. Telos: Critical Theory of the Contemporary 121, lk 11-53.

Pierson, David (toim) 2014. Breaking Bad: Critical Essays on the Contexts, Politics, Style, and Reception of the Television Series. Lanham: Lexington Books.

Plantinga, Carl R. 2011. Folk Psychology for Film Critics and Scholars. Projections 5 (2), lk 26-50 (doi: 10.3167/proj.2011.050203).

Reid, Thomas 1819. An Inquiry into the Human Mind, On the Principles of Common Sense. Glasgow: W. Falconer.

Ryan, Marie-Laure 2001. Narrative as Virtual Reality. Immersion and Interactivity in Literature and Electronic Media. Baltimore \& London: The Johns Hopkins University Press.

Sepinwall, Alan 2012. The Revolution was Televised. The Cops, Crooks, Slingers and Slayers Who Changed TV Drama Forever. Self published.

Shanton, Karen \& Goldman, Alvin 2010. Simulation Theory. Wire's Cognitive Science 1 (4), lk 527-538 (doi: 10.1002/wcs.33).

Smith, Murray 1995. Engaging Characters: Fiction, Emotion, and the Cinema. Oxford: New York: Clarendon Press: Oxford University Press.

Smith, Murray 2011. On the Twofoldness of Character. New Literary History 42 (2), lk 277-294 (doi: 10.1353/nlh.2011.0022).

Sorokin, Siim 2013. Sidusad karakterikavatsused, ebausutavad lood? Kollektiivselt esilduv mõtlemisest mõtlemine teleseriaali "Breaking Bad" internetiretseptsioonis. Ettekanne 57. Kreutzwaldi päevade teaduslikul konverentsil 17. ja 18. detsember.

Sorokin, Siim 2016a. Televaatajate ja karakterite intersubjektiivne ja kontekstuaalne lõimumine teleseriaali "Halvale teele" internetiretseptsioonis. Labi, Kanni (koost, toim). Paar sammukest... Eesti Kirjandusmuuseumi aastaraamat XXIX. Transmeedialised siirded. Võrguteavik. Tartu: EKM Teaduskirjastus, lk 81-108 (doi: 10.7592/PS/29. sorokin). 
Sorokin, Siim 2016b. The Lives of Characters: Affective World-Building in the Internet Discussions of Breaking Bad. Ettekanne rahvusvahelisel konverentsil "The Stories of Hope and Fear: Mapping Emotions and Affects in Life, Arts, and Literature". Eesti, Palmse, 24. ja 25. august.

Sorokin, Siim 2017. Pärisustamise paradoksid: narratiivsed persoonid, "Halvale teele" ja argitarkus netisuhtluses. Ostrak, Anne \& Voolaid, Piret (koost). Variation in language, literature, folklore, and music. Annual conference of the Centre of Excellence in Estonian Studies and annual 61st Kreutzwald Days conference. December 7-8, 2017. Programme and abstracts. Tartu: ELM Scholarly Press, lk 112 (https://www.folklore.ee/CEES/2017/ programme_variation2017.pdf - 4. aprill 2019).

Sorokin, Siim 2018a. Character Engagement and Digital Community Practice: A Multidisciplinary Study of "Breaking Bad". PhD dissertation. Tartu: University of Tartu Press (https://dspace.ut.ee/handle/10062/59057 - 14. veebruar 2019).

Sorokin, Siim 2018b. Teleseriaalide tegelaskujud otsekui pärisinimesed: Argitarkuslikult väljenduv teisetaju sotsiaalmeediavestlustes. Vikerkaar 4-5, lk 104-114.

Sorokin, Siim 2018c. Characters perceived as other people: significance of common sense making in digitally communicated televisual engagement. Ettekanne rahvusvahelisel interdisciplinaarsel konverentsil "Personification Across Disciplines", Durhami Ülikool, 17.-19. september.

Sorokin, Siim (ilmumas). Paradoxical Everyday Imaginaries? Realitization, Narrative Persons and Common Sense Making in Digitally Communicated Televisual Engagement of Breaking Bad. Voolaid, Piret \& Babič, Saša (toim). Variation Turns the World Go Round: Variation in Folklore and Literature. Tartu: Cambridge Scholars Publishing.

Sorokin, Siim n. d. Article review of Murray Smith's On the Twofoldness of Character (2011) (https://www.academia.edu/12253269/Article_review_of_Murray_Smiths_On_ the_Two-foldness_of_Character_2011_-8. märts 2019).

Stilwell, Jessica M. 2003. Fans Without Pity: Television, Online Communities, and Popular Criticism. MA Thesis. Washington DC: Georgetown University.

Thagard, Paul 2000. Coherence in thought and action. Cambridge, Mass.: MIT Press

Thao, Trân Duk \& Muller, Robin 2009. From Phenomenology to the Materialist Dialectic of Consciousness. Muller, Robin (tlk). Graduate Faculty Journal 30 (2), lk 297-325 (doi: 10.5840/gfpj200930221).

Turvey, Malcolm 2003 [1997]. Seeing Theory: On Perception and Emotional Response in Current Film Theory. Allen, Richard \& Smith, Murray (toim). Film Theory and Philosophy. New York: Oxford University Press, lk 431-457 (doi: 10.1093/acprof:o so/9780198159216.003.0020).

Turvey, Malcolm 2006. Imagination, Simulation, and Fiction. Film Studies 8, lk 116-125 (doi: 10.7227/FS.8.12).

Vaage, Margrethe Bruun 2014. Blinded by familiarity: partiality, morality, and engagement with TV series. Nannicelli, Ted \& Taberham, Paul (toim). Cognitive Media Theory. New York \& London: Routledge, lk 268-284. 
Vološinov, V[alentin]. N[ikolajevitš]. 1973 [1930]. Marxism and the Philosophy of Language. Leningrad/ New York ja London: Seminar Press.

Vygotsky, L[ev] S. 1978 [1930]. Mind in society: the development of higher psychological processes. Cambridge: Harvard University Press.

Vygotsky, L[ev]. S. 1986 [1934]. Thought and language. Cambridge, Mass.: MIT Press.

Walton, Kendall L. 1990. Mimesis as Make-Believe. On the Foundations of the Representational Arts. Cambridge \& London: Harvard University Press.

Werth, Paul 1999. Text worlds: representing conceptual space in discourse ( $1^{\text {st }}$ print). Harlow: Longman.

Wulff, Hans Jürgen 1992. Fernsehkommunikation als parasoziale Interaktion: Notizen zu einer interaktionistischen Fernsehtheorie (http://www.derwulff.de/2-35 - 27. mai 2018).

Wulff, Hans Jürgen 2006. Attribution, Konsistenz, Charakter. Probleme der Wahrnehmung abgebildeter Personen. Montage / av, 15 (2), lk 45-62 (https://core.ac.uk/download/ pdf/56716993.pdf - 8. märts 2019).

\title{
Summary
}

\section{Paradoxical everyday imaginaries? Realitization, narrative persons and Breaking Bad}

\author{
Siim Sorokin \\ Research Fellow (Culture Studies) \\ Institute of Cultural Research \\ University of Tartu \\ siim.sorokin@ut.ee
}

Keywords: everyday imaginaries, narratively "tooled" language, narrative person, pragmatics of narrative experientiality, realitization, realmaking, social materialism of narrative, vernacular

The present article elucidates and elaborates on the key theoretical and analytical positions developed in my doctoral dissertation on character engagement, based on the microanalysis of digital storytelling in the online reception of Breaking Bad (Sorokin 2018a). The article (1) gives a general synopsis of the American television series Breaking Bad; (2) provides an analysis of the empirical material in order to illustrate the validity of the theoretical conceptualization; and (3) further teases out the underlying theoretical implications. By design, the theoretical discussion builds on the empirical analysis and focuses, for the purposes of this article, specifically on three core notions and concepts in the previously developed theoretical framework. I use the concept of narrative person to counter the mechanistic, internalist approach to the "fictional character". 
Under my treatment, a narrative person is a sovereign agency by whom the audience is gradually absorbed, as opposed to being absorbed in it. Naturally, such assumptions undermine the universal applicability of internalist models of narrative, in general, and experiential character engagement, in particular. Hence, realitization is envisioned to highlight the discursive practice of "realmaking" in the articulative process of character engagement for the sake of communal discussion. Finally, the concept of co-elaborative creative vernacular indicates communally developed and communicated other-directed distributed sense-making, which is commonsensical and narratively co-elaborated and grounded in everyday language and conceptual thinking which is materialist in character. 